\title{
Optimasi Dosis Pupuk Anorganik dan Pupuk Kandang Ayam pada Budidaya Tomat Hibrida (Lycopersicon esculentum Mill. L.)
}

\section{Dosage Optimization of Inorganic Fertilizer and Chicken Manure in Hybrid Tomato Cultivation (Lycopersicon esculentum Mill. L.)}

\author{
Haveel Luthfyrakhman, Anas D. Susila*
}

Departemen Agronomi dan Hortikultura, Fakultas Pertanian, Institut Pertanian Bogor (Bogor Agricultural University), J1. Meranti, Kampus IPB Darmaga, Bogor 16680, Indonesia Telp.\&Faks.62-251-8629353 e-mail agronipb@indo.net.id

\begin{abstract}
The objective of this research was study the effect of fertilizer and manure on growth and productivity of hybrid tomato (Lycopersicon esculentum Mill. L). This research conduced at Pasir Sarongge experimental field University Farm, Bogor Agricultural University, Cipanas, from February to July 2011. The experimental design used was Completely Randomized Block Design, with two factors and three replications. The first factor was manure dosages which were 0, 10, 20, and 30 ton $\mathrm{ha}^{-1}$. The second factor was fertilizer dosages which were 0\%, $75 \%$, and $150 \%$ of recommended dosage. Recommended dosage use was $100 \mathrm{~kg} \mathrm{ha}^{-1} \mathrm{~N}, 100 \mathrm{~kg} \mathrm{ha-1} \mathrm{P}_{2} \mathrm{O}_{5}$, and $50 \mathrm{~kg} \mathrm{ha}^{-1} \mathrm{~K}_{2} \mathrm{O}$, from Ministry of Agriculture. Plant height showed quadratic response to manure at 2 and 4 week after transplanted (WAT), then linier at 6 WAT. To the fertilizer, plant height showed no response at 2 WAT and has not shown linier response at 4 and 6 WAT. Interaction between manure and fertilizer was significant at 8 WAT. Manure gave linier effect to number of leaves at 2, 4, and 8 WAT but not significant at 6 WAT. Fertilizer gave no significant effect to number of leaves. Manure gave quadratic effect where as fertilizer gave linier effect to fruit weight per plot, fruit weight per hectare estimated, and relative yield. Optimum manure dose obtained from this research was 24.375 ton ha-1. Maximum fruit weight per plot was $17.41 \mathrm{~kg}$. Estimated maximum fruit weight per hectare was 22.79 ton $\mathrm{ha}^{-1}$. Manure gave linier effect to fruit weight per plot of grade A and B. Fruit weight per plot of grade $C$, fruit diameter, and average fruit weight were not affected by manure or fertilizer given.
\end{abstract}

Keywords : tomatoes, fertilizer, chicken manure, Lycopersicon esculentum

\section{ABSTRAK}

Tujuan dari penelitian ini adalah untuk mempelajari pengaruh pupuk kandang ayam dan pupuk anorganik serta interaksinya terhadap pertumbuhan dan hasil tanaman tomat hibrida. Penelitian ini dilakukan di Pasir Sarongge kebun Percobaan University Farm, Institut Pertanian Bogor, Cipanas, bulan Februari sampai Juli 2011. Rancangan percobaan yang digunakan adalah Rancangan Acak Lengkap, dengan dua faktor dan tiga ulangan. Faktor pertama adalah dosis pupuk yang terdiri dari 0, 10, 20, dan 30 ton ha-1. Faktor kedua adalah pupuk dosis yang terdiri dari $0 \%, 75 \%$, dan $150 \%$ dari dosis yang dianjurkan. Penggunaan dosis yang dianjurkan adalah 100 $\mathrm{kg} \mathrm{ha}{ }^{-1} \mathrm{~N}, 100 \mathrm{~kg} \mathrm{ha}^{-1} \mathrm{P}_{2} \mathrm{O}_{5}$, dan $50 \mathrm{~kg} \mathrm{ha}^{-1} \mathrm{~K}_{2} \mathrm{O}$, rekomendasi dari Departemen Pertanian (2002). Tinggi tanaman menunjukkan respon kuadratik terhadap pupuk kandang pada 2 dan 4 minggu setelah transplantasi (MST), dan linier pada 6 MST. Terhadap pupuk anorganik, tinggi tanaman tidak menunjukkan respon pada 2 WAT, dan belum menunjukkan respon linier pada 4 dan 6 MST. Interaksi pupuk kandang dan pupuk anorganik berpengaruh nyata pada 8 MST. Pupuk kandang memberikan pengaruh linier terhadap jumlah daun pada 2, 4, dan 8 MST tetapi tidak signifikan pada 6 MST. Pupuk anorganik tidak memberikan pengaruh nyata terhadap jumlah daun. Pupuk kandang memberikan pengaruh kuadratik sedangkan pupuk anorganik memberikan pengaruh linier terhadap bobot buah per petak, bobot buah estimasi per hektar, dan hasil relatif. Pupuk kandang dosis optimum yang

\footnotetext{
* Penulis untuk korespondensi. e-mail: anasdsusila@ymail.com
} 
diperoleh dari penelitian ini adalah 24,375 ton ha-1. Bobot buah maksimum per plot adalah $17.41 \mathrm{~kg}$. Perkiraan bobot buah maksimum per hektar adalah 22.79 ton ha-1. Pupuk kandang memberikan pengaruh linier terhadap bobot buah per petak $A$ dan B. Bobot buah per petak kelas $C$, diameter buah, dan bobot buah rata-rata tidak terpengaruh oleh pupuk kandang atau pupuk anorganik yang diberikan.

Kata kunci: Lycopersicon esculentum, pupuk anorganik, pupuk kandang ayam, tomat

\section{PENDAHULUAN}

Tomat merupakan salah satu sayuran yang umum dikonsumsi di dunia. Hal ini dikarenakan tomat bisa dikonsumsi segar maupun dalam bentuk olahan. Tiga produk olahan tomat yang utama adalah tomato preserves, dried tomatoes dan tomatoes based food (Costa and Heuvelink, 2005).

Produksi tomat di Indonesia pada tahun 2009 mencapai 853,061 ton dan telah mengalami peningkatan setiap tahunnya sejak tahun 2006 (Badan Pusat Statistik, 2011). Produksi ini akan terus meningkat seiring dengan meningkatnya kebutuhan masyarakat domestik. Provinsi Jawa Barat merupakan provinsi dengan rata-rata produktivitas tertinggi yaitu sekitar 20 ton ha-1. (Deptan, 2011).

Kesadaran akan pentingnya pertanian berkelanjutan dan kesulitan untuk mendapatkan serta mahalnya harga pupuk anorganik pada kalangan petani mengarahkan penelitian kepada pemanfaatan limbah organik yang murah, tersedia dan ramah lingkungan yang bisa digunakan sebagai pupuk organik. Salah satu sumber pupuk organik yang umum adalah pupuk kandang ayam. Menurut Odoemena (2006) pupuk kandang ayam merupakan sumber yang baik bagi unsur-unsur hara makro dan mikro yang mampu meningkatkan kesuburan tanah serta menjadi substrat bagi mikroorganisme tanah dan meningkatkan aktivitas mikroba, sehingga lebih cepat terdekomposisi dan melepaskan hara. Aplikasi pupuk kandang ayam juga diyakini memperbaiki sifat fisik tanah dan meningkatkan daur hara seperti mengerahkan efek enzimatik atau hormon langsung pada akar tanaman sehingga mendorong pertumbuhan tanaman.

Menurut Kandil and Gad (2010) pada tanah lempung berpasir dan tingkat kesuburan yang rendah pemupukan dengan kotoran ayam bisa meningkatkan pertumbuhan vegetatif dan kualitas hasil panen. Urutan perlakuan yang berpengaruh dari yang paling besar adalah pemberian kotoran ayam, farmyard manure, pupuk NPK mineral, kompos hasil pertanian. Kotoran ayam dan farmyard manure memberikan pengaruh yang nyata terhadap bobot basah dan kering brangkasan, produktivitas dan kualitas buah tomat dibandingkan kontrol berupa perlakuan pupuk NPK.
Penelitian ini akan mengombinasikan penggunaan pupuk anorganik dan pupuk kandang ayam dalam produksi tanaman tomat dalam upaya mengetahui dosis yang memberikan pertumbuhan dan hasil panen maksimal. Menurut Ogbomo (2011) pemberian pupuk anorganik yang dikombinasikan dengan pupuk organik lebih baik dibandingkan hanya pemberian salah satu pupuk organik atau pupuk anorganik saja. Kombinasi pupuk anorganik dan organik merupakan perlakuan yang paling efektif untuk mencapai pertumbuhan dan hasil yang optimal dalam budidaya tomat.

Penelitian ini bertujuan untuk mempelajari pengaruh pupuk kandang ayam dan pupuk anorganik serta interaksinya terhadap pertumbuhan dan hasil tanaman tomat hibrida.

\section{BAHAN DAN METODE}

Kegiatan penelitian dilaksanakan di Unit Lapangan Pasir Sarongge, Cipanas, Bogor selama lima bulan dari Februari hingga Juli 2011. Lokasi memiliki ketinggian $1200 \mathrm{~m}$ dpl.

Bahan yang digunakan pada penelitian ini adalah benih tomat varietas hibrida Marta F1. Bahan tanam lain yang digunakan adalah pupuk Urea $46 \% \mathrm{~N}$, $\mathrm{KCl} 60 \% \mathrm{~K}_{2} \mathrm{O}$, SP $3636 \% \mathrm{P}_{2} \mathrm{O}_{5}$ dan pupuk kandang kotoran ayam petelur, pestisida dengan bahan aktif Famoxadona $22.5 \%$ + Cimoxanilo $30 \%$.

Penelitian faktorial ini disusun dalam Rancangan Kelompok Lengkap Teracak (RKLT) dengan dua faktor. Faktor pertama adalah pupuk anorganik dengan taraf $0 \%$ dosis anjuran (tanpa pupuk anorganik), 75\% dosis anjuran (Urea 127.5 g + SP $36157.5 \mathrm{~g}+\mathrm{KCl}$ $52.5 \mathrm{~g}$ per petak), dan $150 \%$ dosis anjuran pupuk anorganik (Urea $255 \mathrm{~g}+\mathrm{SP} 36315 \mathrm{~g}+\mathrm{KCl} 105 \mathrm{~g}$ per petak). Dosis anjuran rekomendasi dari Deptan (2002) adalah $100 \mathrm{~kg} \mathrm{ha}^{-1} \mathrm{~N}, 100 \mathrm{~kg} \mathrm{ha}^{-1} \mathrm{P}_{2} \mathrm{O}_{5}$ dan $50 \mathrm{~kg} \mathrm{ha}^{-1}$ $\mathrm{K}_{2} \mathrm{O}$. Sedangkan faktor kedua adalah pupuk kandang ayam dengan empat taraf, yaitu 0 ton $\mathrm{ha}^{-1}$ (tanpa pupuk kandang ayam), 10 ton $\mathrm{ha}^{-1}$ (7.5 kg per petak), 20 ton $\mathrm{ha}^{-1}\left(15 \mathrm{~kg}\right.$ per petak) dan 30 ton $\mathrm{ha}^{-1}(22.5 \mathrm{~kg}$ per petak).

Setiap perlakuan diulang sebanyak tiga kali sehingga terdapat 36 satuan percobaan. Satu unit 
percobaan terdiri dari 20 tanaman tomat, dengan sampel pengamatan setiap unitnya berjumlah 5 tanaman sehingga jumlah tanaman yang diamati berjumlah 180 tanaman. Petak yang digunakan sejumlah 36 petak dengan luas masing-masing petak 1.5 x $5 \mathrm{~m}$. Petak percobaan berupa bedengan dengan lebar $0.9 \mathrm{~m}$, tinggi $0.2 \mathrm{~m}$ dan jarak antar bedeng $0.6 \mathrm{~m}$.

Hasil pengamatan yang diperoleh dianalisis dengan analisis ragam dan dilanjutkan analisis regresi. Jika interaksi yang diamati berpengaruh nyata, akan dilihat efek pupuk anorganik dalam setiap level pupuk organik.

Pengolahan tanah dilakukan satu minggu sebelum tanam. Pengolahan tanah dilakukan secara manual. Tanah diolah dan dibentuk menjadi bedengbedeng. Pada saat pengolahan tanah diberikan pupuk kandang sesuai dosis perlakuan. Pupuk kandang ayam diberikan sesuai perlakuan dengan cara disebar merata di atas bedengan yang sudah terbentuk kemudian diaduk dengan menggunakan cangkul agar pupuk kandang ayam dan tanah tercampur. Pemupukan anorganik dilakukan dua kali. Pada saat pindah tanam diberikan pupuk Urea dan $\mathrm{KCl}$ setengah dari dosis masing-masing perlakuan, serta pupuk SP 36 sebanyak dosis penuh masing-masing perlakuan. Pada 4 minggu setelah tanam dilakukan pemupukan susulan Urea dan $\mathrm{KCl}$ setengah dosis perlakuan. Pupuk diaplikasikan melingkar pada setiap satu tanaman.

Benih tomat disemai di dalam tray dengan media campuran tanah dan pupuk kandang dengan perbandingan 1:1. Tray diletakkan di dalam rumah plastik, penyiraman dilakukan dua kali sehari. Bibit dipindahkan ke lapangan pada umur 20 hari atau 4-5 helai daun sudah tumbuh. Bibit ditanam dengan jarak tanam $0.6 \mathrm{~m} \times 0.5 \mathrm{~m}$. Bibit ditanam pada lubang tanam, satu bibit per lubang tanam.

Kegiatan pemeliharaan yang dilakukan meliputi penyiraman, penyiangan gulma, pewiwilan, pengajiran dan pengendalian hama dan penyakit. Upaya pengendalian hama dan penyakit dilakukan secara kuratif, yaitu dilakukan pengendalian jika pada lahan telah terjadi serangan hama dan penyakit yang diperkirakan perlu adanya tindakan pengendalian. Pestisida yang digunakan adalah pestisida dengan bahan aktif Famoxadona 22.5\% + Cimoxanilo 30\% dengan dosis $4 \mathrm{~g} \mathrm{ha}^{-1}$ dan konsentrasi $2.5 \mathrm{~g} \mathrm{~L}^{-1}$ dengan volume semprot $160 \mathrm{~L} \mathrm{ha}^{-1}$. Penyemprotan dilakukan pada 5, 7 dan 9 MST.

Pemanenan dilakukan dua kali seminggu pada saat buah mencapai tahap breakers. Tahap breakers merupakan tahap di mana kurang dari $10 \%$ permukaan buah tomat telah berubah warna dari hijau menjadi merah. Panen pada tahap breakers umum digunakan untuk buah tomat yang akan dipasarkan dalam keadaan segar yang akan didistribusikan ke berbagai wilayah.

Pengamatan dilakukan pada 2, 4, 6 dan 8 MST untuk peubah tinggi tanaman dan jumlah daun. Pengamatan terhadap produktivitas dilakukan pada saat tanaman tomat dapat dipanen dengan peubah meliputi bobot perbuah, diameter buah, bobot buah pertanaman, bobot buah per petak. estimasi bobot buah per hektar, dan pengkelasan buah.

Peubah tinggi tanaman diukur dengan menggunakan meteran. Tinggi tanaman diukur dari permukaan tanah hingga titik tumbuh tanaman. Pengamatanjumlah daun dilakukan denganmenghitung jumlah daun yang sudah terbuka sempurna.

Bobot buah rata-rata diukur satu persatu menggunakan timbangan. Diameter buah rata-rata diukur satu persatu dengan menggunakan jangka sorong. Buah yang diamati untuk peubah bobot buah dan diameter buah rata-rata adalah buah hasil dari tanaman contoh. Hasil pertanaman dihitung dari total bobot buah pertanaman contoh. Hasil per petak didapat dari bobot total buah dari masing-masing petak kemudian dikonversikan ke estimasi hasil per hektar.

Estimasi hasil per hektar dikonversi ke hasil panen relatif. Hasil panen relatif (\%) merupakan perbandingan antara estimasi hasil panen per hektar suatu perlakuan dengan estimasi hasil per hektar yang tertinggi dari semua perlakuan yang diberikan (di mana $0=$ tanpa hasil dan $100=$ hasil panen tertinggi).

Hasil panen relatif $(\%)=$

$\frac{\text { estimasi hasil perhektar perlakuan } \mathrm{x}}{\text { estimasi hasil perhektar perlakuan tertinggi }} \times 100 \%$.

Dilakukan pengkelasan terhadap buah tomat hasil panen dengan deskripsi kelas sebagai berikut; kelas A: diameter $>60 \mathrm{~mm}$ dan keadaan buah mulus, kelas B: diameter 40-60 mm dan keadaan buah mulus atau sedikit rusak, kelas $\mathrm{C}$ : diameter $<40 \mathrm{~mm}$ atau buah rusak layak konsumsi.

\section{HASIL DAN PEMBAHASAN}

Penelitian ini dilaksanakan di Unit Lapangan Pasir Sarongge, University Farm IPB yang memiliki ketinggian $1200 \mathrm{~m}$ dpl. Berdasarkan data yang didapatkan dari Badan Meteorologi dan Geofisika dari Maret sampai Juli 2011, suhu rata-rata di Pasir Sarongge adalah $20^{\circ} \mathrm{C}$, suhu maksimum $27^{\circ} \mathrm{C}$, dan suhu minimum $15^{\circ} \mathrm{C}$. Kelembaban relatif rata-rata adalah $78 \%$. Lama penyinaran rata-rata adalah $48 \%$ atau 4.8 jam perhari. Lama penyinaran yang dimaksud adalah persentase lama penyinaran matahari persepuluh jam. 
Tabel 1. Analisis tanah lokasi percobaan Pasir Sarongge, Cianjur 2011

\begin{tabular}{lll}
\hline Ciri Tanah & \multicolumn{1}{c}{ Nilai } & \multicolumn{1}{c}{ Interpretasi } \\
\hline Tekstur: & $14 \%$ & Liat \\
Pasir & & \\
Debu & $16 \%$ & \\
Liat & $70 \%$ & \\
Ph tanah & 5.7 & Cukup masam \\
$\mathrm{C}$ & $3.86 \%$ & Rendah \\
$\mathrm{N}$ & $0.41 \%$ & Sedang \\
$\mathrm{C} / \mathrm{N}$ & 9 & Rendah \\
$\mathrm{P} 2 \mathrm{O} 5$ & $161 \mathrm{ppm}$ & Tinggi \\
$\mathrm{K} 2 \mathrm{O}$ Morgan & $169 \mathrm{ppm}$ & Sedang \\
$\mathrm{Ca}$ & $1439 \mathrm{cmolc} \mathrm{kg}-1$ & Tinggi \\
$\mathrm{Mg}$ & $1.28 \mathrm{cmolc} \mathrm{kg-1}$ & Sedang \\
$\mathrm{Na}$ & $0.2 \mathrm{cmolc} \mathrm{kg-1}$ & Rendah \\
KTK & $15.70 \mathrm{cmolc} \mathrm{kg-1}$ & Tinggi \\
$\mathrm{KB}$ & $>100 \%$ & Tinggi \\
\hline
\end{tabular}

Hasil analisis Laboratorium Balai Penelitian Tanah, Bogor, 2011

Penyakit yang teramati pada petak percobaan adalah layu bakteri, dan ToMV. Layu bakteri disebabkan oleh Phytophtora infestans. ToMV atau Tomato Mozaic Virus dengan gejala tanaman kerdil, daun berbercak kekuningan, berkerut, dan keriting (Jones, 2008). Hama yang menyerang petak percobaan antara lain belalang (Oxya sp.), ulat buah (Helicoperva $z e a$ ), dan ulat (Spodoptera sp.). Intensitas serangan yang terjadi pada lahan percobaan adalah sebesar 5\%. Pada saat pembentukan buah, teramati kecacatan pada buah. Beberapa dari kecacatan ini seperti cracking, catfacing, blossom end rot, dan malformasi buah. Intensitas serangan yang terjadi adalah sebesar 3\%.

\section{Analisis Kandungan Hara Tanah}

Karakteristik tanah lokasi dilaksanakan penelitian disajikan pada Tabel 1. Hasil analisis menggambarkan karakteristik fisika dan kimia dari tanah yang digunakan dalam penelitian.

Menurut Jones (2008) Tanaman tomat tumbuh baik pada tanah dengan ph 5,5 sampai 6,8. Pada $\mathrm{pH}$ optimal, hara esensial akan tersedia dalam jumlah yang optimal. Secara umum, tanaman tomat akan tumbuh dengan baik pada tanah yang subur, tanah dengan kandungan hara makro $\mathrm{P}, \mathrm{K}, \mathrm{Ca}$ dan $\mathrm{Mg}$ sedang hingga tinggi. Tanaman tomat membutuhkan tanah yang mengandung mikro $\mathrm{Fe}, \mathrm{Mn}$ dan $\mathrm{Zn}$ dalam jumlah yang tinggi. Sedangkan hara makro N, Mg, S dan hara mikro B dan $\mathrm{Cu}$ dalam jumlah sedang.

\section{Tinggi Tanaman dan Jumlah Daun}

Tinggi tanaman tomat pada beberapa tingkat umur dan pada beberapa perlakuan dosis pupuk organik dan pupuk anorganik masing-masing disajikan pada Tabel 2 dan Tabel 3 serta jumlah daun disajikan pada Tabel 4.

Perlakuan pupuk organik dan anorganik berpengaruh terhadap pertumbuhan tinggi tanaman pada 2 hingga 6 MST (Tabel 2). Pupuk organik berupa pupuk kandang ayam memberikan respon kuadratik pada 2 dan 4 MST serta respon linier pada 6 MST. Pupuk anorganik tidak memberikan pengaruh nyata terhadap tinggi tanaman pada 2 MST, namun memberikan respon linier pada 4 dan 6 MST.

Interaksi antara pupuk organik dengan anorganik terjadi pada 8 MST. Tabel 3 dan gambar 1 menjelaskan tentang respon tinggi tanaman karena adanya interaksi tersebut.Karena terdapat interaksi pada minggu ke 8, maka respon tinggi tanaman pada setiap taraf dosis pupuk organik dan anorganik dibahas terpisah, disajikan pada Tabel 3 dan Gambar 1. Pupuk anorganik sebanyak $0 \%$ dan $75 \%$ dosis anjuran menunjukkan respon yang linier, sedangkan pupuk anorganik $150 \%$ dosis anjuran tidak berpengaruh nyata. Pupuk anorganik 75\% dosis anjuran masih lebih baik dibandingkan $0 \%$ dosis anjuran. Pada penelitian ini, interaksi antara pupuk organik dan pupuk anorganik hanya terjadi pada variabel tinggi tanaman $8 \mathrm{MST}$, sehingga secara umum belum bisa disimpulkan bahwa penambahan pupuk organik mampu menurunkan kebutuhan pupuk anorganik. Belum bisa diketahui

Tabel 2. Respon tinggi tanaman $(\mathrm{cm})$ pada setiap taraf dosis pupuk organik dan anorganik pada 2 , 4, 6 dan $8 \mathrm{MS}$

\begin{tabular}{llcccc}
\hline Perlakuan & Taraf & \multicolumn{5}{c}{ Minggu Setelah Tanam (MST) } \\
\cline { 3 - 6 } & & 2 & 4 & 6 & 8 \\
\hline Pupuk & 0 & 14.30 & 37.49 & 63.04 & 101.56 \\
Organik & 10 & 17.10 & 48.28 & 75.29 & 115.99 \\
(ton ha $\left.^{-1}\right)$ & 20 & 17.55 & 49.94 & 82.22 & 116.52 \\
& 30 & 17.74 & 50.61 & 82.38 & 123.30 \\
\hline Respon & & $\mathrm{L}^{* *} \mathrm{Q}^{*}$ & $\mathrm{~L}^{* *} \mathrm{Q}^{* *}$ & $\mathrm{~L} * *$ & - \\
\hline Pupuk & $0-0-0$ & 16.03 & 42.97 & 71.17 & 106.29 \\
Anorganik & $75-75-37.5$ & 16.46 & 47.17 & 76.40 & 118.52 \\
(N-P2O5- & & & & & \\
K2O kg ha $\left.{ }^{-1}\right)$ & $150-150-75$ & 17.53 & 49.6 & 79.68 & 118.21 \\
\hline Respon & & tn & $\mathrm{L}^{* *}$ & $\mathrm{~L} *$ & - \\
Interaksi & & tn & tn & tn & $*$ \\
\hline
\end{tabular}


bagaimana efek kombinasi pupuk organik dan pupuk anorganik terhadap budidaya tomat hibrida secara umum.

Penelitian ini juga mengamati respon jumlah daun pada setiap taraf dosis pupuk organik dan anorganik yang disajikan dalam Tabel 4. Pupuk organik yang diberikan memberikan pengaruh yang linier terhadap jumlah daun pada 2, 4 dan 8 MST serta tidak berpengaruh nyata pada 6 MST. Pupuk anorganik yang diberikan tidak berpengaruh terhadap jumlah daun tanaman tomat. Tidak terdapat interaksi antara pupuk organik dengan anorganik yang diberikan pada jumlah daun yang diamati pada penelitian ini.

\section{Bobot Buah}

Pupuk organik dan anorganik berpengaruh terhadap bobot buah per petak (kg), estimasi bobot buah per hektar (ton) dan hasil panen relatif (\%) disajikan pada Tabel 5. Pupuk organik yang diberikan pada percobaan ini memberikan pengaruh kuadratik terhadap bobot buah per petak, estimasi bobot buah per hektar dan hasil panen relatif, sedangkan pupuk anorganik menunjukkan pengaruh yang linier. Tidak ada interaksi di antara perlakuan dosis pupuk yang diberikan sehingga hanya dibahas efek tunggal yang

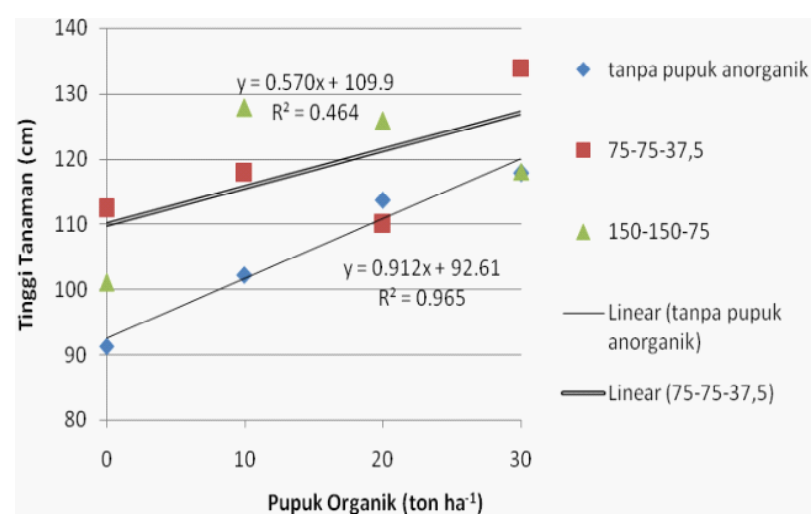

Gambar 1. Pengaruh interaksi pupuk organik dengan anorganik pada tinggi tanaman 8 MST

dihasilkan oleh pupuk organik dan anorganik.

Pada Gambar 2 disajikan respon bobot buah per petak (a), estimasi bobot buah per hektar (b) dan hasil panen relatif (c) pada berbagai taraf dosis pupuk organik. Respon kuadratik yang ditandai dengan adanya titik balik pada kurva menunjukkan bahwa ada dosis optimal yang akan menghasilkan bobot buah per petak, estimasi bobot buah per hektar dan hasil panen relatif yang maksimal. Bobot buah per petak maksimal yang diperoleh pada penelitian ini adalah $17.41 \mathrm{~kg}$

Tabel 3. Pengaruh interaksi pupuk organik dengan anorganik pada tinggi tanaman (cm) umur 8 MST

\begin{tabular}{llrcccc}
\hline & & \multicolumn{4}{c}{ Pupuk Organik (ton ha-1) } & \multirow{2}{*}{ Respon } \\
\cline { 2 - 5 } & & 0 & 10 & 20 & 30 & \\
\hline Pupuk Anorganik & $0-0-0$ & 91.30 & 102.25 & 113.74 & 117.87 & L** \\
(N-P2O5-K2O kg ha-1) & $75-75-37.5$ & 112.33 & 117.82 & 109.98 & 133.96 & L $^{* *}$ \\
& $150-150-1-75$ & 101.03 & 127.90 & 125.83 & 118.07 & tn \\
\hline
\end{tabular}

Tabel 4. Respon jumlah daun pada setiap taraf dosis pupuk organik dan anorganik

\begin{tabular}{llcccc}
\hline Perlakuan & Taraf & \multicolumn{4}{c}{ Minggu Setelah Tanam (MST) } \\
\cline { 3 - 6 } & & 2 & 4 & 6 & 8 \\
\hline Organik & 0 & 5.17 & 8.20 & 10.00 & 12.27 \\
(ton ha-1) & 10 & 6.39 & 9.77 & 10.62 & 12.47 \\
& 20 & 6.08 & 9.59 & 10.94 & 12.15 \\
& 30 & 6.64 & 10.31 & 10.99 & 13.58 \\
\hline Respon & & $\mathrm{L}^{* *}$ & $\mathrm{~L}^{* *}$ & tn & $\mathrm{L}^{*}$ \\
\hline Anorganik & $0-0-0$ & 5.84 & 9.14 & 10.36 & 12.06 \\
(N-P2O5-K2O kg ha-1 ) & $75-75-37.5$ & 6.07 & 9.54 & 10.81 & 13.03 \\
& $150-150-75$ & 6.29 & 9.72 & 10.74 & 12.76 \\
\hline Respon & & tn & tn & tn & tn \\
Interaksi & & tn & tn & tn & tn \\
\hline
\end{tabular}


Tabel 5. Respon bobot buah per petak (kg), estimasi bobot buah per hektar (ton) dan hasil panen relatif (\%) pada setiap taraf dosis pupuk organik dan anorganik

\begin{tabular}{|c|c|c|c|c|}
\hline Perlakuan & Taraf & Bobot Buah Perpertak (kg) & $\begin{array}{l}\text { Estimasi Bobot Buah } \\
\text { Per Hektar (ton) }\end{array}$ & $\begin{array}{c}\text { Hasil Panen Relatif } \\
(\%)\end{array}$ \\
\hline \multirow[t]{4}{*}{ Organik (ton ha-1) } & 0 & 10.62 & 14.16 & 44.06 \\
\hline & 10 & 15.17 & 20.24 & 62.96 \\
\hline & 20 & 16.45 & 21.94 & 68.26 \\
\hline & 30 & 16.37 & 22.31 & 69.41 \\
\hline Respon & & $\mathrm{L}^{* *} \mathrm{Q}^{*}$ & $\mathrm{~L}^{* *} \mathrm{Q}^{*}$ & $\mathrm{~L}^{* *} \mathrm{Q}^{*}$ \\
\hline \multirow{3}{*}{$\begin{array}{l}\text { Anorganik } \\
\text { (N-P2O5-K2O kg ha-1) }\end{array}$} & $0-0-0$ & 12.56 & 16.75 & 52.09 \\
\hline & $75-75-37.5$ & 14.91 & 19.88 & 61.85 \\
\hline & $150-150-75$ & 16.77 & 22.36 & 69.56 \\
\hline Respon & & $\mathrm{L}^{* *}$ & $\mathrm{~L}^{* *}$ & $\mathrm{~L}^{* *}$ \\
\hline Interaksi & & tn & tn & tn \\
\hline
\end{tabular}

buah tomat segar per petak. Estimasi bobot buah per hektar maksimal yang dihasilkan pada penelitian ini adalah sebesar 22.79 ton per hektar. Dosis optimal pupuk kandang ayam adalah sebesar 24.375 ton ha1. Dosis optimal diperoleh dengan cara menurunkan persamaan regresi yang diperoleh dari analisis statistik. Peningkatan pemberian dosis pupuk organik melebihi 24.375 ton ha $^{-1}$ justru akan menurunkan hasil panen tomat.

Koefisien determinasi atau r square dari ketiga persamaan tergolong rendah yaitu hanya sebesar $36.3 \%$. Persamaan mampu menjelaskan $36.3 \%$ pengaruh pupuk organik terhadap hasil panen relatif, sedangkan sisanya dijelaskan oleh faktor-faktor di luar persamaan. Angka koefisien determinasi yang rendah bisa dikarenakan berbagai faktor, di antaranya pupuk anorganik yang diberikan, faktor lingkungan atau galat yang ditimbulkan oleh lingkungan serta kurangnya sampel data yang diamati.

Hasil panen buah segar tomat sebanyak 22.79 ton $\mathrm{ha}^{-1}$ masih tergolong rendah karena berdasarkan deskripsi varietas potensi hasil tomat hibrida Marta adalah sebesar 60-80 ton ha $^{-1}$, namun masih lebih tinggi dibandingkan produktivitas rata-rata Jawa barat yaitu 20 ton $\mathrm{ha}^{-1}$. Salah satu faktor yang paling mungkin menyebabkan rendahnya hasil adalah faktor lingkungan yang tidak bisa dikendalikan, seperti lama penyinaran matahari, curah hujan yang tinggi dan suhu di lokasi penelitian.

Penyinaran matahari yang terlalu singkat mengakibatkan menurunnya kemampuan fotosintesis dan transpirasi tanaman. Penurunan kemampuan tanaman dalam berfotosintesis dan bertranspirasi akan berdampak langsung terhadap pertumbuhan vegetatif dan hasil tanaman tomat. Menurut Jones (2008) meskipun lama penyinaran tidak berpengaruh terhadap pembungaan tanaman tomat, lama penyinaran sangat berpengaruh terhadap hasil.

Curah hujan yang terlalu tinggi juga bisa menjadi penyebab rendahnya hasil. Tanaman tomat membutuhkan air yang banyak, namun tidak dalam jumlah yang berlebihan. Akar tanaman tomat tidak mampu berfungsi dengan baik pada kondisi tergenang (anaerobik). Apabila air di sekitar akar sangat banyak, pertumbuhan tanaman tomat akan terhambat, muncul bunga terlambat, bunga sedikit dan jumlah buah akan menurun. Ketika jumlah air tersedia tidak konsisten, akan banyak terjadi kecacatan pada buah seperti cracking dan blossom-end-rot.

Secara umum suhu yang dibutuhkan tanaman tomat agar tumbuh, berkembang dan berbuah dengan baik adalah $18.5^{\circ} \mathrm{C}$ dan $26.5^{\circ} \mathrm{C}$. Berdasarkan data Badan Meteorologi dan Geofisika, dari Maret sampai Juli 2011 suhu rata-rata di Pasir Sarongge adalah $20^{\circ} \mathrm{C}$, suhu maksimum $27^{\circ} \mathrm{C}$, dan suhu minimum $15^{\circ} \mathrm{C}$. Suhu minimum di lokasi penelitian berada di bawah rentang suhu yang dibutuhkan tomat untuk tumbuh, berkembang dan berbuah dengan baik.

Pupuk anorganik yang diberikan memberikan pengaruh linier terhadap hasil per petak, estimasi hasil per hektar dan hasil panen relatif. Respon linier menunjukkan bahwa belum dapat ditentukan dosis optimal karena variabel yang diamati masih akan 


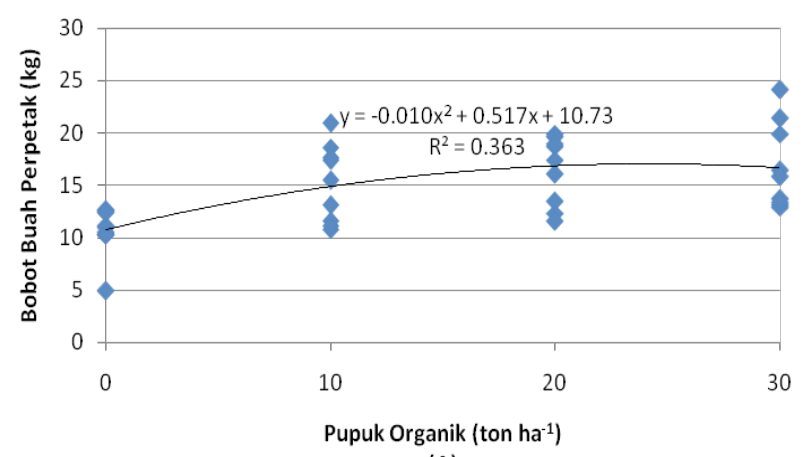

(A)

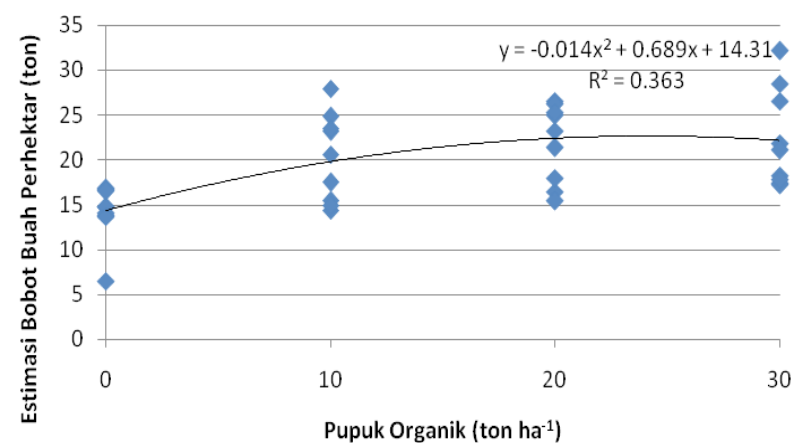

(B)

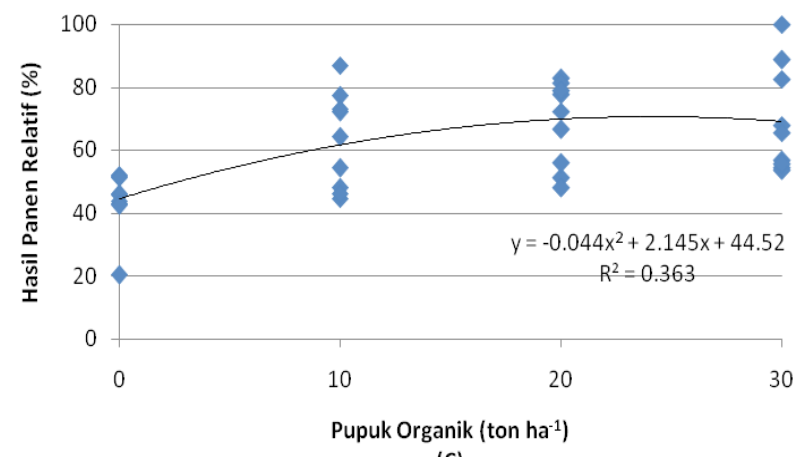

(C)

Gambar 2. Respon bobot buah per petak (a), estimasi bobot buah per hektar (b) dan hasil panen relatif (c) pada berbagai taraf dosis pupuk organik

meningkat seiring penambahan dosis pupuk anorganik yang diberikan. Respon yang masih linier dapat dikarenakan dosis pupuk anorganik yang digunakan kurang tinggi, rentang dosis yang digunakan terlalu sedikit atau jaraknya terlalu jauh.

\section{Pengkelasan Buah}

Pada penelitian ini juga dilakukan pengamatan terhadap bobot buah per petak berdasarkan kelas. Dilakukan pengkelasan terhadap buah tomat hasil panen. Berdasarkan hasil analisis (Tabel 6), pupuk organik dan anorganik memberikan pengaruh yang sangat nyata terhadap bobot buah kelas A dan B, namun tidak berpengaruh terhadap bobot buah kelas C. Dosis

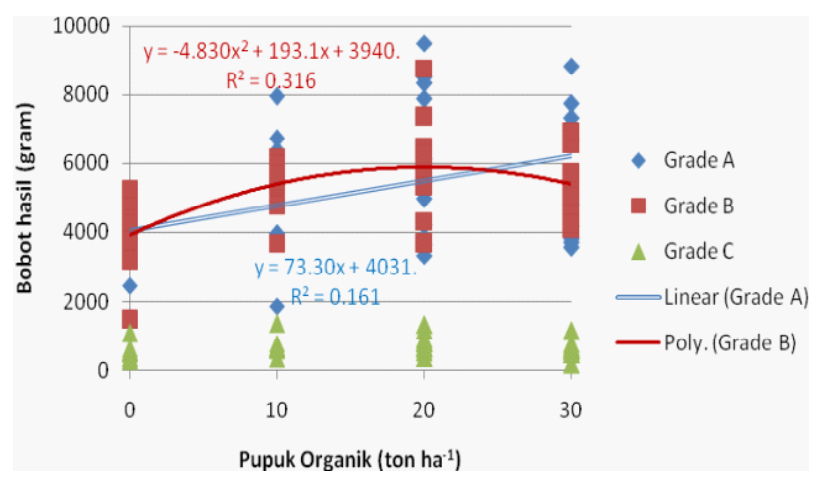

Gambar 3. Respon Bobot Buah Kelas A, B dan C (gram) Per Petak pada Berbagai Taraf Dosis Pupuk Organik (ton ha ${ }^{-1}$ )

pupuk organik memberikan respon linier pada bobot buah kelas A dan kuadratik pada bobot buah kelas B, sedangkan dosis pupuk anorganik memberikan respon linier pada bobot buah kelas A maupun kelas B.

Respon bobot hasil kelas A, B dan C (gram) pada berbagai taraf dosis pupuk organik (ton ha 1) disajikan pada Gambar 3. Bobot buah kelas A masih menunjukkan respon yang linier, sehingga kemungkinan total bobotnya akan terus meningkat seiring dengan peningkatan dosis pupuk organik yang diberikan. Sedangkan bobot buah kelas B menurun apabila dosis yang diberikan sudah melewati dosis optimal bagi buah kelas B yaitu sebesar 19,99 ton ha1. Pupuk organik yang diberikan tidak berpengaruh terhadap bobot buah kelas C.

\section{Ukuran Buah}

Berdasarkan hasil analisis (Tabel 7) tidak terdapat pengaruh dari pupuk organik dan anorganik terhadap variabel diameter dan bobot buah rata-rata. Pengamatan terhadap diameter dan bobot buah ratarata diamati pada setiap buah hasil panen pada semua tanaman contoh.

Tidak ada perbedaan diameter dan bobot buah yang dihasilkan oleh berbagai taraf dosis pupuk organik dan anorganik. Meskipun berpengaruh terhadap bobot buah kelas A dan kelas B, pupuk kandang ayam dan pupuk anorganik yang diberikan ternyata tidak berpengaruh terhadap diameter dan bobot buah ratarata. Hal ini dikarenakan buah kelas A dan kelas B yang dihasilkan jumlahnya tidak terlalu berbeda jauh berbeda sehingga analisis statistik menyatakan tidak ada pengaruh nyata yang dihasilkan oleh perlakuan pupuk organik dan anorganik. 
Tabel 6. Respon bobot buah kelas a, b dan c (gram) per petak pada setiap taraf dosis pupuk organik dan anorganik

\begin{tabular}{llccc}
\hline Perlakuan & Taraf & \multicolumn{3}{c}{ Bobot Buah Per Petak $(\mathrm{g})$} \\
\cline { 3 - 5 } & & Kelas A & Kelas B & Kelas C \\
\hline Organik & 0 & 3606.11 & 3966.11 & 521.67 \\
(ton ha-1) & 10 & 5011.33 & 5310.78 & 694.44 \\
& 20 & 6277.66 & 5948.44 & 792.56 \\
& 30 & 5627.44 & 5360.78 & 600.22 \\
\hline Respon & & $\mathrm{L}^{*}$ & $\mathrm{~L}^{* *} \mathrm{Q}^{* *}$ & tn \\
\hline Anorganik & $0-0-0$ & 3989.67 & 4612.83 & 635 \\
(N-P2O5- & $75-75-37.5$ & 5175.42 & 5012.33 & 656.42 \\
K2O kg & $150-150-75$ & 6226.83 & 5814.42 & 665.25 \\
ha-1 ) & & $\mathrm{L} * *$ & $\mathrm{~L} * *$ & tn \\
\hline Respon & & tn & tn & tn \\
Interaksi & & & &
\end{tabular}

Tabel 7. Respon diameter buah rata-rata ( $\mathrm{mm})$ dan bobot buah rata-rata (gram) pada setiap taraf dosis pupuk organik dan anorganik

\begin{tabular}{|c|c|c|c|}
\hline Perlakuan & Taraf & $\begin{array}{l}\text { Diameter buah } \\
\text { Rata-rata (mm) }\end{array}$ & $\begin{array}{r}\text { Bobot buah } \\
\text { Rata-rata }(\mathrm{g})\end{array}$ \\
\hline \multirow{4}{*}{$\begin{array}{l}\text { Organik } \\
\text { (ton ha-1) }\end{array}$} & 0 & 54.22 & 82.85 \\
\hline & 10 & 53.16 & 79.61 \\
\hline & 20 & 52.86 & 76.80 \\
\hline & 30 & 53.94 & 84.71 \\
\hline Respon & & tn & tn \\
\hline Anorganik & $0-0-0$ & 53.35 & 78.87 \\
\hline & $75-75-37,5$ & 53.67 & 82.11 \\
\hline 1) & $150-150-75$ & 53.61 & 81.24 \\
\hline Respon & & tn & tn \\
\hline Interaksi & & tn & tn \\
\hline $\begin{array}{r}\text { Keterangan : } \\
* *\end{array}$ & $\begin{array}{l}\text { berbeda } n \\
\text { berbeda } n\end{array}$ & $\begin{array}{l}\text { ta pada taraf } \mathrm{p}<0.05 \text {, } \\
\text { ta pada taraf } \mathrm{p}<0.0 .\end{array}$ & \\
\hline L & linier & & \\
\hline Q & kuadratik & & \\
\hline
\end{tabular}

\section{KESIMPULAN}

Penelitian ini telah mendapatkan dosis pupuk kandang ayam yang memberikan pengaruh terbaik terhadap pertumbuhan dan hasil tanaman tomat. Namun untuk pupuk anorganik, belum ditemukan adanya dosis optimal yang memberikan pengaruh terbaik. Interaksi antara pupuk organik dan anorganik yang diberikan hanya terjadi pada variabel tinggi tanaman saat 8 MST.

Dosis pupuk kandang ayam optimal adalah 24.375 ton ha ${ }^{-1}$. Bobot buah per petak maksimal adalah 17.41 $\mathrm{kg}$ per petak. Estimasi bobot buah per hektar masksimal sebesar 22.79 ton $\mathrm{ha}^{-1}$. Dosis optimal ditentukan dari dosis pupuk kandang ayam yang memberikan pengaruh terbaik terhadap hasil panen relatif. Dengan pemberian pupuk kandang ayam sebanyak dosis optimal yang disarankan, pertumbuhan tanaman tomat cukup baik, bobot buah kelas A dan kelas B yang dihasilkan tidak terlalu berbeda. Dosis pupuk kandang yang diberikan tidak berpengaruh terhadap diameter dan bobot buah rata-rata.

\section{DAFTAR PUSTAKA}

Badan Pusat Statistik. 2011. Produksi Sayuran di Indonesia. http://www.bps.go.id. [13 Januari 2011]

Costa, J.M., E. Heuvelink. 2005. Introduction: The tomato crop and industry. In E. Heuvelink $(E d s$.$) . Tomatoes, Crop Production Science in$ Horticulture:13. CABI Publishing. Wallingford, UK. 1-19.

[Deptan] Departemen Pertanian. 2002. Budidaya Tomat. Dirjen Bina Produksi Hortikultura Direktorat Tanaman Sayuran, Hias dan Aneka Tanaman. http://www.deptan.go.id. [13 Januari 2011]

[Deptan] Departemen Pertanian. 2011. Produktivitas Tomat menurut Provinsi. Dirjen Bina Produksi Hortikultura Direktorat Tanaman Sayuran, Hias dan Aneka Tanaman. http://www.deptan.go.id [13 Januari 2011]

Jones, J.B. 2008. Tomato Plant Culture: in the Field, Greenhouse and Home Garden. Taylor and Francis Group. USA.

Kandil, H., N. Gad. 2010. Response of tomato plants to sulphur and organik fertilizer. International Journal of Academic Research 2(3):204-210.

Odoemena, C.S.I.. 2006. Effect of poultry manure on growth, yield and chemical composition of tomato (Lycopersicon esculentum, Mill) cultivars. IJNAS 1(1):51-55.

Ogbomo, L.K.E. 2011. Comparison of growth, yield performance and profitability of tomato (Solanum lycopersicon) under different fertilizer types in humid forest ultisols. Int. Res. J. Agric. Sci. Soil Sci. 1(8): 332-338. 